DEPÓSITO LEGAL ZU2020000153

Esta publicación científica en formato digital

es continuidad de la revista impresa

ISSN 0041-8811

E-ISSN 2665-0428

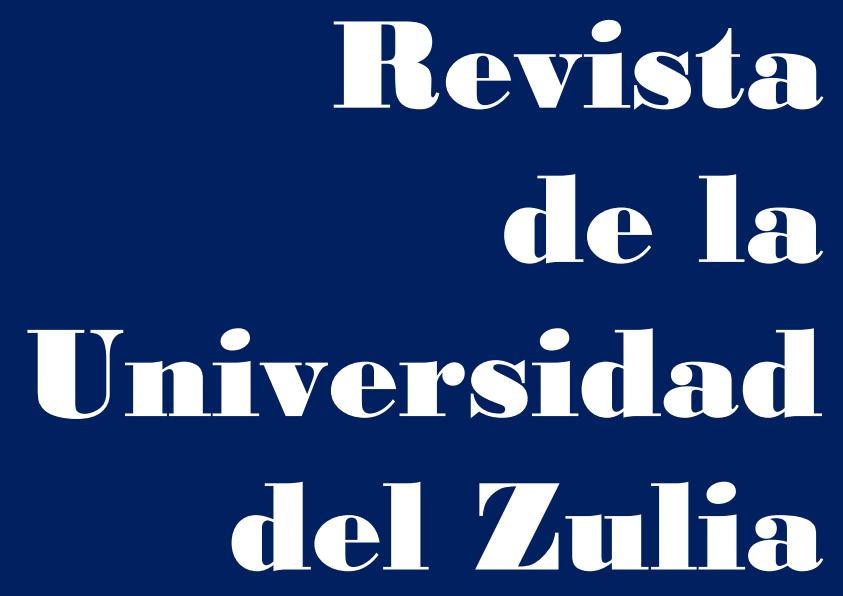

Fundada en 1947

por el Dr. Jesús Emrique Lossada

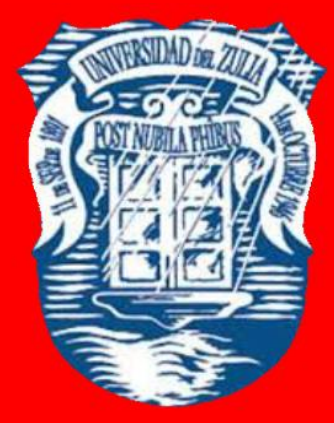

Ciencias

Sociales

y Arte

Año $12 \quad N^{\circ} 34$

Septiembre - Diciembre 2021

Tercera Época

Maracaibo-Veneruela 


\title{
Public procurement in the healthcare sectors of Russia and EEUU
}

\author{
Marina V. Shmeleva *
}

\begin{abstract}
The aim of the study is to analyze public procurement issues in the field of healthcare. Dialectical, logical, and comparative methods have been used. The author has studied the best practices of such procurement and conducted a comparative legal analysis of Russian and the US public procurement systems. The following results have been achieved: it has been found that public procurement in the healthcare sector is considered more complex than that in other sectors of the economy since there are more barriers and travails. This is because through healthcare public procurement the state purchases medical equipment and medications for state and municipal healthcare facilities. The author concludes that one of the main problems in the regulation of healthcare public procurement is that budget holders' supply agreements for medical equipment, medications, and medical products are often competition-free. Covering the efficiency of public procurement in Russia, the author highlights the main violations typical of the system at all levels (from regional authorities to municipal institutions). There are also some practical recommendations to improve Russian public procurement legislation.
\end{abstract}

KEYWORDS: Russian Federation; USA; health services; innovation behaviors; budgets.

* PhD in Law, assistant professor Civil Law Department Saratov State Law Academy, Russia, ORCID: https://orcid.org/0000-0002-1628-8366. Researcher ID: P-6997-2017. E-mail: civil2012@mail.ru 


\section{Contratación pública en los sectores sanitarios de Rusia y EEUU}

RESUMEN

El objetivo del estudio es analizar cuestiones de contratación pública en el ámbito de la asistencia sanitaria. Se han utilizado métodos dialécticos, lógicos y comparativos. El autor ha estudiado las mejores prácticas de dicha contratación y ha realizado un análisis jurídico comparativo de los sistemas de contratación pública ruso y estadounidense. Se han logrado los siguientes resultados: se ha comprobado que la contratación pública en el sector sanitario se considera más compleja que la de otros sectores de la economía ya que existen más barreras y tribulaciones. Esto se debe a que a través de la contratación pública de atención médica, el Estado compra equipos médicos y medicamentos para los centros de salud estatales y municipales. El autor concluye que uno de los principales problemas en la regulación de la contratación pública de atención médica es que los acuerdos de suministro de equipos médicos, medicamentos y productos médicos de los titulares del presupuesto a menudo están libres de competencia. Al cubrir la eficiencia de la contratación pública en Rusia, el autor destaca las principales violaciones típicas del sistema a todos los niveles (desde las autoridades regionales hasta las instituciones municipales). También hay algunas recomendaciones prácticas para mejorar la legislación rusa en materia de contratación pública.

PALABRAS CLAVE: Federación de Rusia; Estados Unidos; servicios de salud; comportamientos de innovación; presupuestos.

\section{Introduction}

Medical services are a social good. That is why effective healthcare public procurement tools are extremely important. In the OECD countries, the public sector provides about three-quarters of the total health system funds. In a number of countries, for example, in Denmark, the UK, and Sweden, up to $80 \%$ of budgets at all levels are spent on health (OECD, 2013).

The main source of healthcare financing in any country is budget funds. Since each country bears the high cost of healthcare, the state is interested in making it more efficient through the procurement of high-quality goods, works and services.

Such violations as miscalculation of the agreement price, its incorrect justification, or the lack of its justification are numerous and costly for the state. As a rule, the vast majority 
of the violations are associated with the purchase of high-tech medical equipment, modern medications for severe and rare diseases as well as foreign-sourced medical products.

The purpose of this study is to assess the efficiency of Russian healthcare public procurement and produce proposals for improving corresponding legislation. The results of the study provide valuable information for the state policy developers and implementers of national strategic plans in the healthcare system.

\section{Research Methods}

The study is based on general scientific methods. The comparative legal method has been used to analyze and compare the characteristics of procurement legislation in Russia and the US. Specific scientific methods have also been applied, e.g. the method of analysis has been used for collecting and summarizing the data from Russian and foreign studies together with the methods of deduction and classification.

\section{Results and Discussion}

Currently, the health systems of most countries of the world are facing daunting challenges even if their priority objective remains the same. The objective is to ensure an effective and sustainable healthcare system in the context of current and projected demographic changes and the needs of the population. The quality and efficiency of medical care and high standards of medical services have always been crucial. Of course, the quality and efficiency of medical care depends on medical equipment. Consequently, the equipment should be procured in a timely manner. This is a long-standing economic and procedural problem in many healthcare systems, which is evidenced by many reports on public procurement as well as scientific works of Russian and foreign researchers.

In recent decades, the health system so many countries have solved many complicated problems. However, the process of demographic aging of the population requires the proper development of legal rules to maintain the healthcare system. It is also necessary to develop effective tools for public procurement. Today, population aging is leading to a decreased portion of working-age people per pensioner. Trends in health indicators among older people are mixed. Severe disabilities have been cut down in some countries but expanded in others. Mild disabilities and chronic morbidities are gradually increasing. 
A decline in the number of able-bodied population will result in a shortage of financial inflows to healthcare systems. An aging population is more susceptible to numerous chronic diseases. Consequently, people will need more medical care. The need to procure highquality medical equipment triggers strong pressures on the state budget.

In the future, the share of public health spending in GDP is expected to grow. This is also confirmed by the population aging forecasts by 2060 . The main factors inducing this avalanche are the following: the demand for high-quality medical services, rising expectations, and steady technological progress.

In Russia, while procurement is being conducted, there are often violations on the part of the health management authorities. At the municipal level, healthcare procurement legislation is regularly violated by public authorities (health departments, ministries, or administrations). At the regional level, potential violators are the local authorities that manage and conduct procurement procedures.

Public inspections often reveal omissions on the part of healthcare duty holders. The omissions are expressed in the lack of control over the execution of agreements, improper registering of agreements, and escaping penalties for non-execution or improper execution of agreements.

At the level of the ultimate beneficiaries, i.e. public (state-owned) and municipal (state-owned) healthcare facilities, the range of procurement legislation violations is much wider. The scope of purchases made by those customers is very extensive: from the repair of medical facilities to the purchase of food for them.

The level of competition lags far behind most countries of the world, even though recently there have been many positive changes in the Russian healthcare public procurement legislation. In Russia, the low efficiency of public procurement stems from many factors, including the abuse of the lowest price criterion while conducting procurement, arrangements for public procurement without any preliminary study of how effective this procurement would be, etc. Nonetheless, public procurement procedures in the Russian healthcare system can get better and more efficient through the use of advanced diagnostic tests and treatment methods.

Up to the present, medical facility managers are likely to make agreements on terms, which are different from the ones specified in the procurement documents and approved by 
the customer. There are also violations of the legislation related to the protocols on the results of the procurement procedures.

This is only a small sample of violations detected in the field of public procurement of medical services, medications, and equipment. Unfortunately, the current Russian legislation does not make it possible (as it has been planned by the legislators) to fully eliminate public and municipal agreements with suppliers, contractors, or implementers affiliated to customers. Thus, the Russian legislators failed to bring new, competitive and transparent relationships into public procurement.

At the same time, violations in the way medical equipment, medical products and medications are supplied have had true negative impact. For example, by extending the delivery time, suppliers unintentionally accelerate a patient's disease progression and provoke geographical, class and racial discrimination in the field of healthcare. Ensuring the supply of high-quality medical products is crucial to address the disparities in the spread of diseases and the related outcomes.

The main goal of each state, conducting procurement for healthcare facilities, is to purchase medical equipment and medications. But at the same time, the state solves other problems, e.g. supporting the development of competition and innovation, helping domestic manufacturers, etc. The regulatory function of the state in the field of public procurement is increasing not only in Russia, but also in the countries where private medical services are very well developed (Improving Public Procurement, 2012). Thus, when the directors of medical facilities conduct procurement, they face a bunch of tasks, including ensuring the quality of purchased medications, treatment tools, and equipment. They also get involved in developing competition, stimulating small and medium-sized businesses, and implementing the imports phase-out policy (Sirotkina and Skrebtsova, 2013).

Many Russian and foreign authors are engaged in research on the efficiency of public procurement. Their main goal is to study the determinants of public procurement and to find ways to make procurement procedures more efficient. As a rule, the contents of the studies is often contradictory. However, these works are rather valuable because they analyze and compare all the ways to solve emerging problems. Most studies analyze such factors as corruption, competitiveness, and transaction costs that affect the efficiency of public procurement (Huculová, 2018; Baldi and Vannoni, 2017; Ochrana and Maaytová, 2012). 
"In the US, patients depend on medical supplies and prescription drugs, which are mainly produced by international companies located in Southeast Asia and Europe. With each US hospital sourcing these products alone, hospital procurement officers are running into a bewildering array of middlemen, international procurement rules, import quotas, and exorbitant freight charges. The quality of public procurement supplies is also a concern, as hospitals face unverified brokers and counterfeit goods.Moreover, as the crisis transitions into a chronic concern, the finances of hospitals, particularly those that serve the safety net, are now at risk. For some hospitals and communities, the purchasing of potentially needed supplies at exorbitant "crisis" prices can become an existential threat. Hospitals require many medical products including PPE and prescription drugs on a regular basis. Most hospitals maintain a procurement officer or department to manage their inventory and order when needed. They do this themselves or through their parent institution. While hospitals can source products themselves through wholesalers, most contract with group purchasing organizations (GPOs), such as Premier Inc. GPOs aggregate demand across many hospitals, buy supplies in bulk, and in many cases obtain better prices for products than individual hospitals can by themselves. In exchange, hospitals pay membership fees to GPOs. GPO memberships are rarely exclusive arrangements, and it is common for a hospital to be a member of multiple GPOs. GPO contracts feature characteristics that make them challenging partners for hospitals when there is a surge in demand or shortage in supply. First, larger purchasers of medical products, including regional/national hospitals, tend to receive preference over smaller hospitals in traditional GPO arrangements. This can lead to disparities in access across hospitals, even in the same city or country. Second, most GPO contracts do not contain "failure to supply" arrangements that would hold them accountable for failing to supply products that they are unable to procure and that hospitals require. This leaves hospitals to source needed products on their own.

Third, there are no product price guarantees in a typical GPO contract. This means that manufacturers of these products can and do charge prices above the contracted amount and what may seem reasonable when there is a surge in demand or in the prices of base products and ingredients. While US states have price gouging laws, cross-border federal laws fall under the umbrella of trade and tariffs and don't prohibit price gouging. Fourth, 
GPO contracts do not guarantee the quality of products that they procure for hospitals. For some products, minimum quality standards set by regulators serve as a backstop. For example, the Food and Drug Administration (FDA) regulates the quality of most prescription drugs and maintains a database of approved PPE manufacturers as a resource to hospitals. However, many products procured by GPOs are not regulated by federal agencies, which incentivizes suppliers to maintain very low-quality standards or even cheat. There is also no public information about the quality of products sold by manufacturers. GPOs and wholesalers have no legal or contractual obligation to provide this information to their members" (Devaiah et al., 2020).

In our opinion, an important element of healthcare public procurement is innovationoriented public procurement (IOPP). Among other tools, it is considered extremely effective, since it allows the state to act as a leading buyer, stimulating the innovative development of domestic companies and achieving social goals.

Innovative public procurement can be defined as the purchase by a medical facility of equipment and medications, which do not yet exist but can be produced by the supplier within a reasonable period. The equipment and medications are to be manufactured on the basis of additional or new research as well as science and technology.

In addition, innovative public procurement contributes to the development of innovations in many ways, e.g. through the use of new methods of treatment that are more effective and painless.

Innovative public procurement is being actively debated all over the world. Though this issue has been studied a lot in Europe, there are very few research papers on this issue in the US. Moreover, American public procurement primarily embraces innovations in the sphere of national defense and security. Most of the strategic procurement in the US is aimed at achieving social goals, e.g. environmental protection, energy conservation, and assistance to socially vulnerable groups.

Thus, the US government encourages the procurement and the development of innovative solutions to meet various social needs. However, a direct reference to the purchase of advanced technologies through federal procurement was found only in one US Executive Order No. 13834 of 17 May 2018. In this Executive Order, "the Congress has enacted a wide range of statutory requirements related to energy and environmental performance of 
executive departments and agencies (agencies), including with respect to facilities, vehicles, and overall operations. It is the policy of the United States that agencies shall meet such statutory requirements in a manner that increases efficiency, optimizes performance, eliminates unnecessary use of resources, and protects the environment. In implementing this policy, each agency shall prioritize actions that reduce waste, cut costs, enhance the resilience of Federal infrastructure and operations, and enable more effective accomplishment of its mission" (Presidential Document by the Executive Office of the President, 2018).

Public procurement can be classified in different ways according to what is procured, for whom, and why.

On the first classification level, there is general and strategic procurement. Any public procurement implemented to meet the buying agency's need for finished products refers to general public procurement. Procurement is considered strategic when the demand for certain technologies, products, or services is spurred in order to boost a certain market.

The next basis for classification is the forms of innovative public procurement. They depend on the level of promoted innovations. Development procurement refers to the acquisition of technologies that must be developed almost from scratch. Adaptive procurement refers to the acquisition of innovations, which are necessary to refine some specific technology when the basic technology already exists (Edquist, Hommen and Tsipouri, 2000).

Another classification of public procurement is based on the end-user of acquired goods, services, and works. Direct public procurement takes place when the final consumer of the things purchased is the Government itself. Cooperative public procurement is defined as joint purchasing, i.e. state-owned companies buy something jointly with private buyers. Afterward, both public and private parties use the purchased innovations. Catalytic public procurement happens when a public agency initiates a purchase, but afterward, the innovation is used exclusively by a private person.

On top of it, three main roles of innovative public procurement have been identified. The creation of a market occurs if there is no market for a procured technology. Market escalation is triggered when there is a stable market for the technology, but it requires further development to attain commercial success. Market consolidation helps to standardize the 
criteria or technical specifications for the technology to be used in the public sector. This entails similar changes in the private sector.

Moreover, serious risks are provoked by restrictions related to public procurement of high-tech medical devices, for example, ultrasound machines. It should be noted that Russia has legislative restrictions for foreign suppliers on the delivery of medical devices and equipment. That is why not all the devices are equally good since in most cases only foreign equipment provides for quick and efficient diagnostics.

We believe it is really good that there are no such restrictions on foreign medications.

The reform of the Russian public procurement system has become an urgent issue in recent decades. It is also essential to realize that investing in innovations is an expensive and risky gamble. An emphasis on minimizing costs and risks in the procurement legislation may impede innovations. Similarly, the tightening of financial management can increase an administrative burden, which would keep the most innovative organizations away from participating in procurement.

The Russian procurement legislation is characterized by a pronounced antimonopoly orientation. Russian procurement procedures seem to be tailored only to one criterion, i.e. the low price. The rules that ban any limitations on the number of participants in procurement apply to almost all purchases in medical facilities, but special attention is paid to the procurement of medications under the Federal Law on the Contract System. Thus, in accordance with Article 33 (1) (6) of the Law, the procurement documents must reveal international unlicensed names of medical drugs. If the procured medications do not have such names, the documents must specify the chemical names and the grouping names of the medications. There are exceptions to this rule, i.e. there are cases where the legislation allows the procurement of medications under their trade names.

First, the procured medicinal product must be on the list of medications approved by the Government of the Russian Federation. The procedure for forming the list is defined by the Government Decree No. 1086 "On approval of the rules for forming the list of medications procured under their trade names and on amendments to the Regulation on the Government Commission on Public Health Protection” of 28 November 2013.

Second, the procurement of medications must be conducted through a request for proposals under Article 83 (2) (7) of the Law on the Contract System. The Article covers the 
procurement of medications that are necessary for prescribing to a patient if there is a corresponding medical need determined by a decision of the medical commission.

Third, the Law restricts the amount of procured medications. It must not exceed the amount of medications needed by the patient during the treatment period.

Fourth, under Article 93 of the Law on the Contract System, the medication must be procured from a single source (supplier, implementer, or contractor).

The current Russian legislation requires customers to undertake marketing research to determine the availability of goods, services, or works, which could meet the customer's requirements, and procure them if necessary. For procurement of goods, services, and works, acquisition procedures and contract terms are simplified. This entails the simplification of procurement documentation and shortening the time for contract performance.

The Russian market for the supply of medications and medical equipment features strong consolidation in the healthcare sector. The public procurement market has become a specialized niche with a limited number of companies and a special range of goods, e.g. cancer drugs, insulin, antibiotics, etc. (Sokolov et al., 2013).

In the field of healthcare, Russian legislators provide for special rules aimed at boosting competition in the market of public procurement of pharmaceuticals. For example, Article 33 (1) (6) of the Law on the Contract System says that medications with the various international unlicensed names or in the absence of such names with chemical and grouping names cannot be a subject of one contract (one lot) provided that the initial (maximum) price of the contract (lot price) exceeds the limit value established by the Government of the Russian Federation.

Russia is taking measures to regulate the market of vital and essential medications due to the social significance of such medical products. Under Article 60 of the Federal Law "On the Circulation of Medicines" of 12 April 2010, the list of vital and essential medications is approved annually by an Order of the Government of the Russian Federation. The Law requires the state registration of the manufacturers' maximum ex-works prices for the medicinal products included in the list of vital and essential medications. By the same Law, executive authorities of the Russian Federation constituent entities are entitled to determine maximum wholesale and maximum retail mark-ups for vital and essential medications. 
The Russian legislation on procurement for state needs prescribes rules for the purchase of medical products from the list of vital and essential medications. Under Article 31 (10) of the Federal Law on the Contract System, at the procurement of medications, which are included in the list of vital and essential ones, dismissal of the procurement participant from participation in determination of suppliers or refusal to conclude the contract with the winner of determination of suppliers is allowed at any time prior to conclusion of the contract if the customer finds out that the maximum sale price of medications offered by such procurement participant is not registered, or the price offered by such procurement participant exceeds maximum sale price (the procurement participant refuses to make it lower).

The medication must be described through converted measurements and registered in the Russian Federation. To convert the measurements, the customer has a right to use any applications and information, including those on the Internet.

According to the definition in Article 4 of the Federal Law "On the Circulation of Medicines", a reference medical product is a medical product which is registered in the Russian Federation for the first time, whose quality, efficacy and safety are proved based on the results of preclinical trials. A generic medical product is a medical product, which has the same qualitative composition and quantitative composition of active substances in the same pharmaceutical form as a reference medical product, but appeared on the market later.

The problem of equivalence of generic medical products is relevant all over the world because the world market is full of medications from different manufacturers. In Russia, this issue is particularly urgent, since the pharmaceutical market is saturated with a large number of medications, and even taking into account the fact that the global consumption of generics is constantly growing (Yagudina, Arinina, and Kondratieva, 2013). Russia occupies one of the leading places with a $77 \%$ share of generics on the market. For example, in the United States, the share of generics is 12\%, in Japan - 30\%, in Germany - 35\%, in France - about 50\% (Presidium Meeting of the Government of the Russian Federation on the development of competition in the markets of air transportation and medicines, 2013). Moreover, several hundred medications from various manufacturers have been registered as having the same active substances. 
The manufacturer of the reference medical product invests funds at all the stages of drug development, i.e. from the search for the active substance to the study of the most effective combinations with auxiliary substances, which eventually becomes a medication. Studies confirm the effectiveness and safety of the developed drug in specific pathologies. Pharmaceutical companies receive patent protection for it for a long period (up to 20 years or more), which allows them to compensate for the enormous costs of developing an innovative medication and promoting it on the market, paying for many years of work of highly paid specialists, clinical research and, of course, to earn income. Manufacturers change the composition, use less refined raw materials and auxiliary substances. The medication gets brought to the market often without having a single clinical study confirming its effectiveness and safety (Sirotkina and Skrebtsova, 2021).

The Russian Federal Antimonopoly Service considers that the drug form, the international unlicensed name, and its dosage are decisive for the buyer.

Thus, according to the Letter of the Federal Antimonopoly Service dated August 30, 2011, in accordance with Article 61 of the Law on the Circulation of Medicines, similar medicines are medicines with the same names, the same drug forms and the same dosages. The Federal Antimonopoly Service of Russia believes that similar medicines should be referred to as interchangeable medicines in the context of the Law on Protection of Competition. However, this approach contradicts the understanding of the therapeutic equivalence of medications.

However, there are exceptions. When there are differences in the amount and bioavailability of the active substance contained in the instructions for use, the drug form, the route, and other inconsistencies that the customer considers important for one reason or another. Such medications will not be considered interchangeable even within the framework of one international unlicensed name. This is evidenced by a number of Federal Antimonopoly Service regulations and court decisions.

After analyzing the explanations of the International Pharmaceutical Federation (FIP) and the International Federation of Pharmaceutical Manufacturers and Associations (IFPMA), it can be concluded that they focus on controlling therapy in the interests of patients, which means promoting adherence to a particular treatment. The aforementioned organizations draw attention to the fact that therapeutic equivalence must be proved for 
each medication of each specific manufacturer, taking into account the fact that the generics containing the same active pharmaceutical substance are not therapeutically equivalent. Therefore, they are not interchangeable. This evidence should be based on scientifically sound data. A specific decision on the replacement of the medication should be based on medical specifics but can be based on the information provided in the relevant manual.

According to the Decree of the Russian Government No. 1380 in the description of the object of purchase, you must not specify:

1) The drug form (packaging), for example, a vial or a blister;

2) The requirements for the pharmacodynamics and/or the pharmacokinetics of the medication, for example, the start time, the manifestation of the maximum effect, and the duration of the medical product effect;

3) Other characteristics of medications contained in the instructions for the use of medicinal products that reveal their manufacturer.

Thus, the driving force should be the cooperation between suppliers and customers. Customers and suppliers will benefit from cooperation by identifying the best commercial practices and determining the need for their implementation.

Now, contracts, which are based on the results of procurement procedures, assume that customers fix their requirements for the purchased product, service, or work in the terms of reference. They determine in advance what they want. Consequently, there is a very limited opportunity for contractors to provide their own ideas. Therefore, it is necessary to introduce an innovative type of contract, which could be concluded at the early stages of product development.

Price is always an important factor in public procurement, but it cannot be decisive in innovative procurement. The search for the best value should become an essential factor when purchasing high-tech products. "Cost realism" should also be used to determine whether the overall concept makes sense to the customer.

The main results of the study include the following:

1) Proposals have been developed to improve the tools for healthcare public procurement;

2) The analysis of regulations on public procurement in Russia and the US has been carried out. 
REVISTA DE LA UNIVERSIDAD DEL ZULIA. 3época. Año $12 \mathrm{~N}^{\circ}$ 34, 2021

Marina V. Shmeleva // Public procurement in the healthcare sectors of Russia and EEUU, 150-166 DOI: http://dx.doi.org/10.46925//rdluz.34.10

\section{Conclusions}

The public procurement system reform has become an urgent issue in recent decades. The study reflected the best practices in the sphere of public procurement, comparing them to the habitual practices of the Russian government.

The analysis of typical violations of procurement legislation in the field of healthcare shows that the requirements for mandatory and timely publication of information about the planned procurement, information about concluded and executed agreement, and the maintenance of procurement registers are not very well observed. Violations also happen when determining the procurement method. Illegal actions are often made by the procurement committees when determining the procurement winners. The committees are able to illegally prohibit a potential candidate from participation in procurement and reject his/her application. During inspections, cases of illegal requirements, being included by customers in the procurement documents, including those that establish administrative barriers and restrict competition, have been revealed.

As a result of the conducted research, we have found that in recent years, the concerns of limited budgetary financing and the problems of the public procurement system efficiency in the healthcare sector have become obvious. In this regard, it is important to build a more effective system of healthcare public procurement. As stated in some WHO reports, almost a fifth of health spending does not contribute to improving people's health and/or the contribution is not enough.

Reforming the public procurement system in the healthcare sector requires much time. In particular, it is necessary to more precisely regulate the procedure for conducting procurement in health care systems, aiming at spending less budget funds. At the same time hospitals are equipped with high-quality and modern medical equipment and medications. The solution to the problem is to conduct two-stage procurement procedures, where at the first stage the customer only places the task that he needs to be done, and suppliers would offer their own solutions. At the second stage, the procurement procedure should take place directly with the consideration and evaluation of applications. This can be a two-stage competition or a two-stage request for proposals.

There are also other serious problems in the healthcare system, such as the provision of fictitious bank guarantees, illegal changes introduced by the parties into the terms of 
agreements as well as expanding the range of goods supplied, resulting in an increase in the contract price. There are still cases of improper performance by contractors (suppliers) of obligations stipulated in agreements in the absence of proper control by customers as well as their failure to take measures to impose penalties and terminate improper agreements.

We propose the following legislative changes that would help make the public procurement process in the healthcare sector more efficient:

1) To abandon the low price main criterion. In such procurement priority should be given to those goods, works, and services that meet the interests of therapeutic treatment of patients;

2) To conduct and stimulate procurement of innovative and high-tech goods, works and services;

3) To include the concept of "therapeutic equivalence of medications" in the legislation;

4) To create an information and analytical system for monitoring and controlling public procurement of medications that would meet modern requirements;

5) To provide for a special procurement procedure in the legislation to fight emergency threats like COVID 19.

\section{Acknowledgments}

The reported study was funded by the Russian Foundation for Basic Research, scientific project No. 20-011-00140 A: "The Introduction of modern civil law mechanisms in the field of public procurement as a system of measures to ensure efficient use of budget funds as well as conditioning positive structural changes in the economy and social sphere", 20202022.

\section{References}

Baldi, S.; Vannoni, D. (2017). The impact of centralization on pharmaceutical procurement prices: The role of institutional quality and corruption. Regional Studies, 5l(3), 426-438. doi:10.1080/00343404.2015.1101517.

Devaiah A., Wijaranakula M., Kommuru Rena C., Conti R. M. (2020). Product Procurement In A Time Of Federalism: The COVID-19 Challenge. URL: 
REVISTA DE LA UNIVERSIDAD DEL ZULIA. $3^{a}$ época. Año $12 \mathrm{~N}^{\circ}$ 34, 2021 Marina V. Shmeleva // Public procurement in the healthcare sectors of Russia and EEUU, 150-166 DOI: http://dx.doi.org/10.46925//rdluz.34.10

https:/www.healthaffairs.org/do/10.1377/hblog20200515.360276/full/ (accessed on 25 February 2021).

Edquist C., Hommen L., Tsipouri L. (2000). Public technology procurement and innovation. Kluwer Academic Publishers, Boston, Dordrecht, London.

Federal Law "On the Circulation of Medicines" of 12 April 2010 https://clineg.com/laws-inrussia/federal-law-61 (accessed on 20 June 2021).

Federal Law on the Contract System https:/en.fas.gov.ru/netcat files/File/44 FZ\%20eng.pdf (accessed on 20 June 2021).

Government Decree "On approval of the rules for forming the list of medications procured under their trade names and on amendments to the Regulation on the Government Commission on Public Health Protection" of 28 November 2013 https://base.garant.ru/70522140/ (accessed on 20 June 2021).

Government Decree on Medicine Descriptions URL: https://base.garant.ru/71810812/ (accessed on 20 June 2021).

Huculová, E. (2018). Porovnanie vybraných metodologických prístupov HTA na národnej úrovni a naúrovni nemocníc. Exclusive journal: economy and society and environment 2018, 6(4), 5359.

Improving Public Procurement. Recommendations and materials prepared by the Industrial Companies Working Group (2012), Moscow.

Letter of the Federal Antimonopoly Service URL: https://drcs.krasnodar.ru/content/134/show/6880/\#: : text=Письмо\%20ФАС\%20России\%2 0от\%2030,МHН».\%2011\%20сентября\%202016\%2С\%20Воскресенье (accessed on 20 June 2021).

Ochrana, F.; Maaytová, A. (2012). Starting points for creating a transparent and noncorruption public procurement system. Ekonomický časopis, 60 (7),732-745.

OECD (2013). Health at a Glance 2013: OECD Indicators, OECD Publishing. http://dx.doi.org/10.1787/health glance-2013-en (accessed on 20 June 2021).

Presidential Document by the Executive Office of the President on 05/22/2018. Efficient Federal Operations. URL: https://www.federalregister.gov/documents/2018/05/22/20181110l/efficient-federal-operations (accessed on 25 December 2019).

Presidium Meeting of the Government of the Russian Federation on the development of competition in the markets of air transportation and medicines, 2013. URL: http://government.ru/news/8354 (accessed on 25 December 2019).

Sirotkina, N.G.; Skrebtsova, R.R. (2015). The Characteristics of Procurement Procedures in State-Financed Healthcare Facilities of the Russian Federation. MEDICAL ALMANAC, 4(39). 


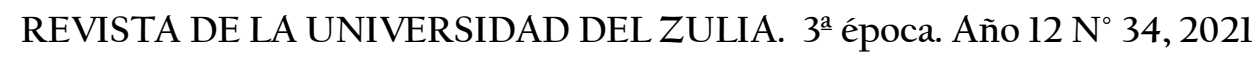
Marina V. Shmeleva // Public procurement in the healthcare sectors of Russia and EEUU, 150-166 DOI: http://dx.doi.org/10.46925//rdluz.34.10

https://publications.hse.ru/mirror/pubs/share/folder/dzx8nj0ocv/direct/171938284 (accessed on 20 June 2021).

Sokolov, B.I.; Lin A.A.; Terekhov M.E. (2013). Pharmaceutical Market: Wholesale Sector. Problems of the Modern Economy, 2 (46).

Yagudina R.I., Arinina E.E., Kondratieva B.B. (2013). Interchangeability and Substitutability of Medicines. Modern Organization of Medication Supply, 1. 